\title{
Correction to: Paracrine signaling in islet function and survival
}

\section{Sean M. Hartig ${ }^{1,2} \cdot$ Aaron R. Cox ${ }^{1}$}

Published online: 28 April 2020

(C) Springer-Verlag GmbH Germany, part of Springer Nature 2020

\section{Correction to: Journal of Molecular Medicine https://doi.org/10.1007/s00109-020-01887-x}

The corrected References in Table 1 are presented in this paper.

Table 1 Genetic models used in islet paracrine signaling studies

\begin{tabular}{|c|c|c|c|c|c|}
\hline Model & Target & Cre driver & Goal & Caveats & Reference \\
\hline bTC6-F7 cell IR overexpression & insulin receptor & N/A & gain of function & & [49] \\
\hline bTC6-F7 cell IR kinase dead & insulin receptor & N/A & loss of function & & [49] \\
\hline beta cell specific IR KO & insulin receptor & Insulin I Cre knockin & loss of function & & [64-66] \\
\hline $\mathrm{BIRKO}$ & insulin receptor & Rat insulin II promoter & loss of function & $\begin{array}{l}\text { promoter contains hGH minigene; } \\
\text { deletion in brain }\end{array}$ & {$[52,53]$} \\
\hline beta IGF-1R KO & IGF-1 receptor & Rat insulin II promoter & loss of function & $\begin{array}{l}\text { promoter contains hGH minigene; } \\
\text { deletion in brain }\end{array}$ & {$[55,57]$} \\
\hline beta double IR IGFR KO & IR and IGF-1R & Rat insulin II promoter & loss of function & $\begin{array}{l}\text { promoter contains hGH minigene; } \\
\text { deletion in brain }\end{array}$ & {$[57]$} \\
\hline alpha cell IR KO & insulin receptor & glucagon promoter & loss of function & & {$[11]$} \\
\hline delta cell IR KO & insulin receptor & SST-Cre & loss of function & not specific to islet delta cells & {$[125]$} \\
\hline GcgR null mice & GcgR & N/A & loss of function & & {$[83,84]$} \\
\hline beta cell GcgR KO & GcgR & Mouse insulin I promoter & loss of function & promoter contains hGH minigene & {$[92]$} \\
\hline beta cell GcgR overexpression & GcgR & Rat insulin II promoter & gain of function & $\begin{array}{l}\text { promoter contains hGH minigene; } \\
\text { deletion in brain }\end{array}$ & {$[78]$} \\
\hline GLP-1R null mice & GLP-1R & N/A & loss of function & & [92] \\
\hline SSTR2 null mice & SSTR2 & N/A & loss of function & & {$[122]$} \\
\hline SSTR5 null mice & SSTR5 & N/A & loss of function & & {$[74]$} \\
\hline SST-Cre;R26-DTA & Somatostatin+ cells & SST-Cre & loss of function & & {$[124]$} \\
\hline Ghrelin null mice & Ghrl & N/A & loss of function & & {$[134]$} \\
\hline Ghrelin receptor null mice & Ghsr & N/A & loss of function & & {$[134]$} \\
\hline ZnT8 null mice & Slc30a8 & N/A & loss of function & & {$[41]$} \\
\hline
\end{tabular}

The online version of the original article can be found at https://doi.org/ 10.1007/s00109-020-01887-x

Aaron R. Cox

racox@bcm.edu

1 Division of Endocrinology, Diabetes, and Metabolism, Department of Medicine, Baylor College of Medicine, Houston, TX 77030, USA

2 Department of Molecular and Cellular Biology, Baylor College of Medicine, Houston, TX 77030, USA 